\title{
Austerity in Civil Procedure and the Role of Simplified Procedures
}

\author{
Xandra Kramer \& Shusuke Kakiuchi*
}

\section{Introduction}

The civil justice system has been in a constant flux in the past decades due to changes in society and litigants' behaviour, as well as the increased factual and legal complexity of cases. The number of cases has been steadily increasing in many countries while the available budget required for more judicial staff, improving judicial case management, digitalisation of processes, and the required specialisation, has not in all instances increased at the same pace. This was worsened as a result of the recent financial crisis that affected many countries around the globe and has prompted governments to cut back on public expenditure. Austerity further challenges the demands of effective justice within a reasonable time,${ }^{1}$ as is in the European context notably enshrined in Article 6 of the European Convention on Human Rights (ECHR). ${ }^{2}$ The financial crisis also led to a decrease in the funding of legal aid by the government in a number of countries, challenging access to justice for more vulnerable litigants in particular.

The present issue (8:4) of Erasmus Law Review results from one of the sessions of the XV World Congress of Procedural Law of the International Association of Procedural Lam in 2015, dedicated to 'Effective Judicial Relief and Remedies in an Age of Austerity'. ${ }^{3}$ It focuses on the role of simplified civil procedures against the background of austerity. The articles included in this issue are fully redrafted versions of a selection of the national reports prepared for the general report for this conference, authored by the present editors. ${ }^{4}$ Simplified pro-

Xandra Kramer is a professor at Erasmus School of Law, Erasmus University Rotterdam, and Deputy Judge at the District Court of Rotterdam. Shusuke Kakiuchi is a professor at the University of Tokyo.

1. A.A.S. Zuckerman, Civil Justice in Crisis: Comparative Perspectives of Civil Procedure, OUP, 1999, at 3-52 pointed out the delay in civil procedure as being a result of an ineffective organisation of civil justice as the primary bottleneck, and it is still one of the primary issues in civil procedure.

2. See also for example Article 47 of the Charter of Fundamental Rights of the European Union and Principle 9 of the ALI/UNIDROIT Principles of Transnational Civil Procedure. This rule is also included in many domestic codes.

3. XV World Congress of Procedural Law, 25-28 May 2015, Istanbul.

4. X.E. Kramer and S. Kakiuchi, 'Relief in Small and Simple Matters in an Age of Austerity', Working paper XV Congress of Procedural Law, available at SSRN: <http://ssrn.com/abstract=2610773>. The general report is based on nineteen national reports. cedures typically are procedures for small value and uncontested claims or similar simple cases that do not merit a full procedure. The availability of such procedures may evidently contribute to easier and cheaper access to justice, as they usually have a lower threshold and require less formalities (e.g. lower court fees, no legal representation, less documentation). Also for governments, these types of procedures may be attractive from the viewpoint of austerity as those procedures generally require lesser use of resources.

This issue includes nine articles that each deal with simplified procedures and austerity issues in a particular jurisdiction. Three articles discuss European jurisdictions: Belgium (Stefaan Voet), England and Wales ${ }^{5}$ (John Sorabji), and Spain (Laura Carballo Piñeiro and Jordi Nieva Fenoll). Two articles concern distinct Asian countries: Israel (Ehud Brosh) and Japan (Etsuko Sugiyama). One article addresses an African country: Ghana (Ernest Owusu-Dapaa and Ebenezer Adjei Bediako). Three articles focus on American jurisdictions; North America: the United States (Manuel Gomez and Juan Carlos Gomez) and Canada (Jon Silver and Trevor Farrow), and South America: Brazil (Antonio Gidi and Hermes Zaneti Jr.).

This article will frame and provide an overview of simplified procedures in the nine jurisdictions, discuss the effects of austerity on civil procedure and the role of simplified procedures. Most countries have directly or more indirectly suffered from the recent economic downturn, with the exception of Brazil, and this has had a greater or lesser influence on government spending on the judiciary, legal aid, court fees, litigation behaviour of parties, and the development of simplified procedures. In all countries, simplified procedures play a role in the quest to enhance efficiency in civil justice.

\section{Simplified Procedures}

\subsection{Significance of Simplified Procedures in a Judicial System}

Simplified procedures are court procedures that are distinguished from fully equipped ordinary civil procedures by curtailing or omitting certain procedural steps. In most jurisdictions, they are considered a response to the need for inexpensive and quick procedures, in par-

5. Further referred to as England 
ticular in simple and small matters. ${ }^{6}$ However, since the demand for inexpensive and quick procedures is not unique to small and simple matters, the significance of simplified procedures is not always limited to such matters.

\subsubsection{Need for Inexpensive and Quick Procedures in Simple and Small Matters}

The connection between simplified procedures and simple and small matters can be explained from two perspectives, namely the viewpoint of the litigants and that of the provider of procedural institutions, which is normally the state.

Firstly, from the litigants' viewpoint, i.e. the demand side, an inexpensive and speedy procedure is required if the amount of the claim is low. Otherwise, litigants would be deterred from bringing their claim to court, due to the disproportionate burden of costs and time. This would be inacceptable from the viewpoint of access to justice. Thus, from the litigants' viewpoint, and that of claimants in particular, ${ }^{7}$ the value of the claim and the resources to be spent on the recovery have to be proportionate.

Secondly, from the supply-side perspective, the major concern is the appropriate allocation of judicial resources. It is desirable to avoid unnecessary costs and to allocate resources in proportion to the importance of the matter. As a general rule, if the amount of the claim is low, it is justified to allocate fewer resources to these compared to matters of a higher monetary value. However, other than monetary interests at stake, such as the desire of furthering the development or uniform application of the law, may sometimes lend a matter greater importance. Hence, in small and simple matters, simplified procedures are generally preferable to the ordinary ones from the state's as well as from the litigants' perspective. ${ }^{8}$

\subsubsection{Demand for Simplification of Procedures in a Broader Context}

It should be noted that the demand for inexpensive and speedy procedures is not limited to small and simple matters. It is an ideal for any civil procedure, since every procedure should be carried out at reasonable cost and within a reasonable time. Simplification of procedures is an issue for the whole judicial system. ${ }^{9}$ This explains the fact that in some countries, where the problem of costs of or delays in civil justice is grave, special attention is paid to simplified and consequently less expensive and quicker procedures. ${ }^{10}$ For this reason simplified procedures are of great significance in the context of austerity.

\subsection{Forms and Techniques of Simplified Procedures}

\subsubsection{Need for Cost Reduction and the Procedural Design} Concerning the concrete design of simplified procedures, the following remarks can be made. First, the claimants' and the defendants' interests need to be distinguished. Whereas claimants generally have an incentive to choose a less expensive and speedy procedure, defendants might prefer a fully equipped procedure with full procedural guarantees. This raises the question as to who chooses the procedure and how. Indeed, if claimants and defendants have different interests, to which party's preference should priority be given? This is also related to the question as to in how far procedural justice should be guaranteed in such simplified procedures. If a simplified procedure is applicable against one party's will, a minimum standard of procedural justice should be guaranteed.

Second, concerning the costs of procedures, consideration must be given as to for whom the procedure should be inexpensive. A speedy procedure is speedy for everyone, but an inexpensive procedure is not necessarily so, since it depends on how the costs of the procedure are allocated between the state and the parties. An inexpensive procedure for litigants is generally, but not necessarily, cheap for the state and vice versa. ${ }^{11}$ Although it is true that, in most cases, a simplified procedure costs less than a fully equipped procedure, both for litigants and the state, how far costs can be reduced depends on the concrete technique of simplification. Here again, the question of minimum procedural justice arises, since there is often a trade-off between the pursuit of cost reduction, in particular from the perspective of the government, and procedural justice.

Thus, the design of simplified procedures depends on the way in which different interests, namely the interest
6. See also Kramer and Kakiuchi, above n. 4, at 10-13.

7. The situation changes, however, if one focuses on the interest of the defendant. See Section 2.2.1 below.

8. However, consideration must be given as to for whom the procedure should be inexpensive. See Section 2.2.1.
9. It may be added that historically, it was not unusual that a summary procedure was used practically as the ordinary procedure, as was the case for the 'processus summarius' of the Bavarian Judicial Code (Codex juris bavarici judiciarii) of 1753. Similarly, there are many instances where an originally simplified special procedure subsequently replaces the ordinary procedure, as it was seen in the generalisation of the 'written procedure with the oral closing argument' (schriftliches Verfahren mit mündlicher Schlußverhandlung) to the ordinary procedure by an ordinance of 1846 (Verordnung über das Verfahren in Zivilprozessen vom 21.6.1846) in Prussia. Moreover, even the whole history of the Roman civil procedure can be described as a succession of transitions from an ordinary, formal procedure to a simplified one (from legis actiones to formulary procedure and from formulary to cognitio procedure).

10. See Kramer and Kakiuchi, above n. 4, at 12-13 for an example from Egypt.

11. See also Kramer and Kakiuchi, above n. 4, at 12-13 for an example from Venezuela. 
of the claimant, defendant, and the state, are dealt with, on the one hand, and the balance between cost reduction and procedural justice, on the other.

\subsubsection{Types of Cases and the Simplification of Procedures}

Although, as was discussed in Section 2.1, the need for simplification of civil procedures is common to the whole judicial system, small and simple matters are the field where simplification is most typically needed in view of the proportionality requirement and is justified by the limited interests and the simplicity of the case.

The following type of cases can be distinguished, each requiring a different procedural designs. First, there are 'small' matters in the sense of matters of relatively little importance. A small matter in this sense is often a synonym for a matter having a low monetary value. ${ }^{12}$ Second, there are 'simple' matters in the sense that they do not raise difficult questions of law or fact. Such matters can be further divided into the following subcategories. The first category is cases where the opponent party does not contest the claim. In such cases, the claim can be enforced without any trial on the merits. A typical solution for this type of case is the procedure of order for payment. The second type consists of cases raising no hard question to resolve, although the opponent party does contest the claim. This includes, for instance, cases where there is no question on the interpretation of the law and the claim or the defence is supported by strong evidence leaving no reasonable prospect of refutation as well as stereotype cases that fit within a highly routinised operation.

In short, small and simple matters can be divided into the following three categories: (i) matters of small importance, (ii) matters, where the opponent party does not (manifestly) contest the claim, and (iii) matters without complicated issues notwithstanding the opponent party's objection. From the viewpoint of the required procedural design, the situation is basically the same in small matters (type (i)) and cases without complicated issues (type (iii)), whereas uncontested cases (type (ii)) are a clearly distinguished category. Accordingly, we can place the first group under the general heading of 'small and simple matters' and the second group more specifically under 'uncontested cases'. Whereas summary procedures of a unilateral nature, in particular the procedure of order for payment, are commonly used for uncontested cases, for small and simple matters generally simplified contradictory (not unilateral) procedures are used, although their features vary considerably per jurisdiction.

\subsection{Overview of the Simplified Procedures in the Nine Jurisdictions}

\subsubsection{Unilateral Summary Procedure (Order for Payment)}

The aim of unilateral summary procedures - the procedure of order for payment - is to enable claimants to obtain a title of execution to enforce their claim in a

12. See Section 2.1.1 above. quick and simple way without formal trial proceedings, particularly in cases where the claim appears to be unproblematic and is not contested. This type of procedure has been traditionally used in civil law countries, particularly in Germany and those countries which were heavily influenced by the German legal system. Of the nine jurisdictions discussed in this issue, the procedure of order for payment or a similar procedure exists in Belgium, Spain, ${ }^{13}$ Ghana, ${ }^{14}$ Japan, ${ }^{15}$ and Brazil. ${ }^{16}$ Canada, England, ${ }^{17}$ Israel, and the United States do not have an order for payment procedure, but the summary judgement to some extent fulfils a similar function, though its scope of application is broader. On the pan EU level, the European order for payment procedure was adopted, which is available in cross-border cases only and on an optional basis.

The main feature of the order for payment procedure is that the opponent party, the alleged debtor, is not heard and the claim is not or hardly examined on the substance. Although the basic structure of the procedure is the same in the above-mentioned jurisdictions, there are some differences concerning in particular (i) the structure of the procedure (two-stage or single-stage procedure $\left.^{18}\right)$, (ii) the extent to which the court examines the claim (only formal or a more substantial examination of the claim), and (iii) the applicability criteria (with or without financial limit). The German procedure adopts the combination of a two-stage procedure with only formal examination and no financial limit, which is largely followed by Japan. The European order for payment procedure is a single-step procedure where only a limited review takes place on the basis of a description of the evidence. A similar procedure exists in Spain. From the viewpoint of procedural guarantee, a more substantial review by the court may compensate to some extent the limitation of the opportunity given to the debtor to oppose the claim.

Among the nine jurisdiction included in this issue, the Belgian procedure is a distinct model, as it adopts the combination of a two-stage procedure with a substantial examination of the claim by the court. In addition, it is the only jurisdiction limiting the applicability of the procedure with a financial limit of $1,860 \mathrm{EUR} .{ }^{19} \mathrm{It}$ is not

13. See Carballo and Nieva in the present issue.

14. Ghana belongs basically to the common law tradition. However, the procedure referred to as 'undefended list' appears to be the equivalent to the payment order system. See Owusu-Dapaa and Bediako in the present issue.

15. See Sugiyama in the present issue.

16. The Brazilian procedure is referred to as 'monitory action'. It should be noted, however, that this procedure is different from the European order for payment procedure in terms of the structure and scope. See Gidi and Zaneti in the present issue.

17. However, as far as cross-border cases are concerned, the European order for payment procedure (Regulation (EC) 1896/2006 of the European Parliament and of the Council of 12 December 2006 creating a European order for payment procedure) is applicable also in England.

18. In the two-stage procedure, the chance to oppose the claim is given twice to the debtor, whereas in the single-stage one, such an opportunity is granted in principle just once to the debtor.

19. This limit was abolished for claims falling under the jurisdiction of the Commercial Court in 2014. However, for other claims, the limit is maintained. See Voet in the present issue. 
surprising that this procedure is considered unsuccessful as it is hardly used; ${ }^{20}$ a reform proposal is pending.

\subsubsection{Simplified Contradictory Procedures}

As was discussed earlier, simple and small but contested matters require simplified procedures from the viewpoint of the claimant and to some extent that of the state. At the same time, adequate procedural guarantees should be in place for the defendant in particular. Such a small claims procedure exists in most of the nine jurisdictions, including Brazil, Canada, England, Israel, Japan, Spain, and the United States, with the exception of Belgium ${ }^{21}$ and Ghana. ${ }^{22}$ In the EU, the European small claims procedure is currently available in crossborder cases with a value up to $€ 2,000{ }^{23}$

In order to provide inexpensive and quick relief, these procedures make use of various techniques, including (i) reduced court fees, (ii) shorter timer limits, (iii) use of standardised forms, (iv) encouraging parties to settle, (v) limitations on counterclaim, and (vi) limitations on evidence. In addition, in common law countries, rules applicable to the ordinary procedure, such as rigorous disclosure and strict rules of evidence, may be exempted or alleviated. In the small claims procedure in England, referred to as the 'small claims track', disclosure is only required for documents that parties intend to rely upon, and strict rules of evidence are excluded. ${ }^{24}$ Similarly, in the United States, the often complicated discovery process normally does not apply in the small claims procedure. $^{25}$

142 As far as the above-mentioned procedural techniques are concerned, there is little substantial difference between countries, although the degree of application varies. However, an interesting divergence appears as regards the methods applied to examine the case. On the one hand, in some jurisdictions, the simplified procedure may be conducted in writing. A typical example of such a procedure is found in Germany. ${ }^{26}$ Among jurisdictions discussed in this issue, a written procedure is available in England, although the consent of both parties is required. ${ }^{27}$ The same idea of speeding up the pro- cedure and reducing costs by in principle conducting the procedure in writing is found in the European small claims procedure. On the other hand, there are several countries where the orality of the procedure is considered to be the main feature of the simplified procedure. This is typically the case for the so-called verbal procedure in Spain, which aims to examine the case in just one oral hearing. ${ }^{28}$ In Brazil, orality is one of the major features of the small claims procedure. ${ }^{29}$

Another issue on which countries diverge is whether an appeal is allowed against the decision rendered in a simplified procedure. This question is in fact closely related to the question of parties' right to request an ordinary procedure. ${ }^{30}$ Whereas there are jurisdictions such as England, ${ }^{31}$ which allow appeals without special limitation, the possibility of appeal in the small claims procedure is limited in a few jurisdiction. This is, for instance, the case in Israel, where an appeal is allowed only with the leave of the appellate court. ${ }^{32}$ Japan goes one step further and fully excludes appeal in the small claims procedure. ${ }^{33}$

The actual use of simplified small claims procedures varies considerably per country. There are some countries where the procedure is used often. In England, the vast majority of civil claims are dealt with in the small claims track. ${ }^{34}$ The same applies to several major states in the United States, where a significant use of the small claims model is reported. ${ }^{35}$ In contrast to these jurisdictions, in Japan, there were 12,109 filings in the small claims procedure in 2013, representing a decrease compared to the 23,584 filings in 2005. ${ }^{36}$

It should be noted that the number of filings does not always correspond to the attractiveness of the procedure, because it depends to a great extent on whether the procedure is mandatory or optional. ${ }^{37}$ In many jurisdictions the small claims procedure is considered to be effective, including in particular England, Israel, Japan, and the United States.
20. The procedure received only 658 filings in 2013, which means $0.1 \%$ of the incoming cases before justices of the peace in Belgium. See Voet in the present issue.

21. In Belgium, although there is the Justice of the Peace, which is regarded as a small claims court, its procedure is the same as the ordinary one. See Voet in the present issue.

22. It appears that there is no procedure specialised in small matters in Ghana.

23. This monetary threshold will be raised, see Section 3.2.

24. See Sorabji in the present issue. Similar relaxation of evidence rules is reported for small claims courts in Israel as well. See Brosh in the present issue.

25. See Gomez and Gomez in the present issue.

26. See Kramer and Kakiuchi, above n. 4, at 27-28.

27. It is also worth mentioning that in a few common law countries, where particular costs and burdens are caused by the formal trial proceeding, it is important to know how a trial may be avoided. This is why the summary judgement is emphasised in these countries as a method to resolve cases without formal oral hearings. See Silver and Farrow, Owusu-Dapaa and Bediako and Gomez and Gomez in the present issue. See further Silver and Farrow in the present issue for summary trial as a device to simplify the trial instead of avoiding it completely.
28. See Carballo and Nieva in the present issue.

29. See Gidi and Zaneti in the present issue. Japan may be added to this group, because in the Japanese procedure for actions on small claims, the oral hearing constitutes the essential part of the procedure and may not be omitted. See also Sugiyama in the present issue.

30. See Kramer and Kakiuchi, above n. 4, at 29.

31. See Sorabji in the present issue.

32. See Brosh in the present issue.

33. See Kramer and Kakiuchi, above n. 4, at 30. See also Sugiyama in the present issue.

34. See Sorabji in the present issue.

35. See Gomez and Gomez in the present issue. See also Silver and Farrow in the present issue reporting that in Ontario, Canada, over $60 \%$ of civil suits have been handled under the simplified procedure.

36. See Sugiyama in the present issue.

37. It is, thus, not surprising that the English small claims procedure is much used, because the procedure is basically mandatory for certain categories of claim. See Sorabji in the present issue. 


\section{Austerity Effects on Civil Procedure and Simplified Procedures}

\subsection{Austerity and Civil Procedure}

Austerity has a number of effects on civil procedure, as is also evident from the articles included in this issue. From the perspective of the government as the supplier of civil justice, measures are undertaken to 'economise' civil procedure, in other words to reduce costs and to generally make civil procedures more efficient. At the same time, in times of economic downturn, the demands of litigating parties may shift. As is clear from some of the articles, increasing efficiency is not only imposed by austerity concerns but also aims at making justice more effective and increasing access to justice for litigants. $^{38}$

Not all nine countries discussed in this issue have suffered equally from the recent economic crisis with resulting austerity measures affecting civil justice. On the contrary, in Brazil, economic growth during the last few decades has facilitated investments in the judiciary and resulted in increased legal aid. It is evident that the extent to which austerity has an effect on civil procedure also depends on the government's contribution to the financing of the court system and legal aid for parties. However, at all times, there is a need to keep the judiciary cost within the designated available budget. Some countries have experienced specific periods of economic crisis in the past, for instance Israel in 2001-2003, ${ }^{39}$ or generally have limited financial resources. Ghana as a developing country relies heavily on financial support and investments of developed countries, and its vulnerable economy was consequently affected by the recent financial crisis. ${ }^{40}$

\subsubsection{The Supply Side of Civil Fustice}

Austerity primarily influences the overall financing of the judicial system, the provision of legal aid, court fees, and the introduction or expansion of simplified court procedures and alternative dispute resolution (ADR). For the European Union, the EU Justice Scoreboard of 2015 noted that many Member States were in the process of justice reforms that were necessitated, among others, by the need to cope with budgetary constraints. ${ }^{41}$ A report of the European Network of Councils for the

38. In relation to Canada, it is stated that there is no empirical evidence to back up a correlation between austerity measures in response to the global crisis and the challenges to access to justice that Canada faces. See Silver and Farrow in the present issue.

39. See Brosh in the present issue.

40. See Owusu-Dapaa and Bediako in the present issue.

41. EU Justice Scoreboard 2015, 3 (Figure 1), available at: <http://ec. europa.eu/justice/effective-justice/files/justice_scoreboard_2015_en. $\mathrm{pdf}>$
Judiciary (ENCJ) also pointed to severe budget cuts in a number of European countries. ${ }^{42}$

Budget cuts have been most severe in England and Spain in recent years. In England, as part of the need to reduce public spending, the justice budget required reduction by over a third from 2010 to 2016, and this has had consequences for the civil courts. ${ }^{43}$ Eligibility for legal aid has been dramatically reduced already since the end of the 1990's, but was further reduced by $40 \%$ in 2013. At the same time, court fees have been raised substantially with the aim of ensuring that the English civil courts are entirely self-funding. In Spain, during the worst years of the economic crisis, the investment in justice was dramatically reduced, from $€ 90$ per inhabitant in 2010 to $€ 25$ in 2012 . $^{44}$ Legal aid is reduced, and while court fees were abolished in 1986, they were reintroduced for legal persons in 2002. A law of 2012 extending court fees to natural persons was eventually abolished due to public pressure. In Belgium, according to Voet, austerity has been an important issue for decades and the general perception is that the judicial system is always underfunded. ${ }^{45}$

In Japan, the budget for the judiciary was substantially reduced in the past years. ${ }^{46}$ Though Israel was not heavily affected by the recent financial crisis there are austerity concerns. These, according to Brosh in the present issue, correlate heavily with 'the long-standing Israeli preoccupation with speeding up justice' that has resulted in a range of measures to simplify procedures.

Economic downturn in recent years has also had its effect on the vulnerable economy of Ghana, and Owusu-Dapaa and Bediako describe the relationship between the economy and the effectiveness of the civil justice system as symbiotic. ${ }^{47}$ Litigation is relatively expensive in Ghana, while legal aid is only limitedly available. They describe the indirect effect of the financial crisis on civil justice as quite spectacular. There has been a huge increase in courts fees $(400 \%$ for filing a notice of appeal), which is not solely but at least in part a result of the economic crisis. It particularly affects the position of low-income citizens. In addition, the activities of several courts were suspended, increasing the need to travel.

In the United States, the direct effects on civil justice of governmental cutbacks necessitated by the financial crisis are limited, as Gomez and Gomez explain, ${ }^{48}$ and as was noted earlier by Marcus. ${ }^{49}$ Legal aid provided by the government has always been limited, and thus, the economic burden of litigation is transferred to private litigants. Silver and Farrow analyse the access to justice

42. ENCJ, Judicial Reform in Europe - Report 2011-2012, at 15, available at: <www.encj.eu/images/stories/pdf/GA/Dublin/encj_report_judicial_ reform_def.pdf>.

43. See Sorabji in the present issue.

44. See Carballo and Nieva in the present issue.

45. See Voet in the present issue.

46. From 333,106 million yen in 2006 to 320,122 million yet in 2011 and 311,100 million yes in 2014. See Sugiyami in the present issue.

47. See Owusu-Dapaa and Bediako in the present issue.

48. See Gomez and Gomez in the present issue.

49. R. Marcus, 'Procedure in a Time of Austerity', International Journal of Procedural Law 3 (2013), at 133-158. 
crisis in Canada, though they underline that there are no empirical data to back up a correlation between austerity measures in response to the global crisis and the challenges of access to justice. ${ }^{50}$ Litigation is complex and time consuming, and legal aid is limited, though in recent years the funding of legal aid has been increased. An increase in court fees in British Columbia was found to unconstitutionally restrict access to justice by the Supreme Court.

In most countries, alternative dispute resolution (ADR) has been actively promoted in recent years. In all three European jurisdictions discussed in this issue, mediation and other forms of out-of-court dispute resolution play an increasingly important role. This is triggered by developments at the EU level, where a Mediation Directive for cross-border cases was adopted in 2008, ${ }^{51}$ followed by a Directive on Consumer ADR and a Regulation on Consumer ODR (online dispute resolution) in 2013. ${ }^{52}$ In England, since 2012, small claims are automatically referred to mediation, while retaining the voluntary nature of mediation. ${ }^{53}$ In Belgium, for small consumer disputes, an ADR and ODR system (BelMed) was introduced in 2011 with a view of keeping these disputes out of the court system. In Spain, way is made to mediation and consumer arbitration as well.

In other countries, ADR is also on the rise or had acquired a steady position already, such as in the United States, Canada, and Japan. In Ghana, ADR is strongly advocated, and in commercial matters, parties are obliged to attend a pre-trial settlement conference. In its 2014 Budget Statement, the government underlined the importance of ADR as a cost-saving mechanism. ${ }^{54}$ In relation to Israel, Brosh refers to 'a vigorous - bordering on aggressive - promotion of alternative dispute resolution, especially mediation, in order to induce parties to settle without trial'. ${ }^{55}$ In Canada various forms of courtordered and court-assisted mediation have emerged as well as court-assisted court settlement schemes (pre-trial mediation conferences; judicial dispute resolution, or judicial-assisted dispute resolution). ${ }^{56}$

Brazil is an outlier in this regard, although ADR is facilitated by a recent act. Litigation is relatively cheap, and Brazil is still investing in comprehensive legal aid, a development that Gidi and Zaneti rightly describe as being against the worldwide trend of austerity. The authors warn for facilitating free justice as 'there is no free lunch, a Justice entirely dispensed by public entities

50. Silver and Farrow in the present issue.

51. Directive 2008/52/EC of the European Parliament and of the Council of 21 May 2008 on certain aspects of mediation in civil and commercial matters, OJ 2008, L 136/3.

52. Directive 2013/11/EU on alternative dispute resolution for consumer disputes and amending Regulation (EC) No 2006/2004 and Directive 2009/22/EC (Directive on consumer ADR), OJ 2013, L 165/63 and Regulation (EU) No 524/2013 on online dispute resolution for consumer disputes and amending Regulation (EC) No 2006/2004 and Directive 2009/22/EC (Regulation on consumer ODR), OJ 2013, L 165/1.

53. Thus, it is no compulsory mediation, as Sorabji sets out in the present issue.

54. See Owusu-Dapaa and Bediako in the present issue.

55. See Brosh in the present issue.

56. See Silver and Farrow in the present issue. must be entirely financed by taxes paid by citizens: this may not be a sustainable recipe in the long run, as the European reality has demonstrated' ${ }^{57}$

\subsubsection{Changing Litigant Behaviour}

In most countries, austerity is believed to also have had an effect on the behaviour of litigants. In several countries, including Spain, the number of cases increased during the financial crisis. A direct result in countries affected by the financial crisis was an proliferation of certain cases, in particular insolvency cases and debt collection procedures. ${ }^{58}$

A specific change in the litigation landscape that is particularly highlighted in the articles on Belgium, Spain, and Japan is an increased demand for legal aid, which is vital in particular in small claims cases and other simplified procedures where consumers are involved. For instance, in Belgium, the demand has increased steadily over the past decades and has doubled in recent time. In 2013, the Belgian legislator proposed a set of measures in an attempt to tackle the 'budgetary explosion'. ${ }^{59}$ The global shift in litigation funding schemes from legal aid provided primarily or exclusively by the government to other types of funding ${ }^{60}$ is in particular highlighted in the articles on England, Canada, and the United States; in the latter, legal aid provided by the government has traditionally been limited. Private legal aid insurance, third-party funding, and private funding by way of contingency fees are on the rise. Particularly, in the United States, a fast-growing industry of third-party funding and crowd funding is noted, the latter also in relation to small claims cases.

In a number of countries where legal representation is generally not compulsory, there is an increase in unrepresented litigants. In England, as a result of severe cutbacks on legal aid funding by the government, the number of litigants in person has steadily increased. As Sorabji argues, this challenges the adversarial principle. It has also led to a rapid increase of litigation assistance by usually untrained other persons and fee-charging professionals ('McKenzie Friends'), which Sorabji refers to as 'counsel of despair'. ${ }^{61}$ In Ghana, natural persons are often represented by court clerks, bailiffs, and commissioners of oath because they cannot afford a professional lawyer, and this weakens their position. ${ }^{62}$ Pro se litigation rates have also increased in Canada, and the most common reason for individuals to represent themselves is simply because they cannot afford legal counsel. Despite efforts to tackle the problem of self-representa-

57. See Gidi and Zaneti in the present issue

58. See also Frans van Dijk and Horatius Dumbrava, 'Judiciary in Times of Scarcity: Retrenchment and Reform', International Journal for Court Administration 17 (2013), with reference to a questionnaire of the European Network of Councils for the Judiciary (ENCJ).

59. See Voet in the present issue.

60. For an extensive comparative study on the costs and (changes in) the funding of civil litigation, see Chris Hodges, Stefan Vogenauer \& Magdalena Tulibacka, The Costs and Funding of Civil Litigation, Oxford, Oxford University Press (2010).

61. See Sorabji in the present issue.

62. See Owusu-Dapaa and Bediako in the present issue. 
tion, including the establishment of self-help guides - as they have also emerged in England - this is, according to Silver and Farrow, a significant concern. ${ }^{63}$ In the United States, defendants in small claims debt-collection cases are usually unrepresented. Though there are many efforts countrywide to assist unrepresented litigants, Gomez and Gomez note that abuse by debt collecting agencies is a major problem in small claims cases. ${ }^{64}$ A mirror effect of the wide facilitation of ADR by governments is the increased use by justice seekers of various forms of out-of-court dispute resolution. In some countries, (semi) compulsory forms of mediation have been introduced, including in Ghana and several Canadian provinces. In a number of other countries, ADR is increasingly used in small claims cases, including Spain, Belgium, Japan, and the United States. An extensive report of 2014 on the use of mediation in the EU reveals that as yet less than $1 \%$ of the cases are resolved through mediation. ${ }^{65}$ However, it may be expected that the new European ADR and ODR instruments will boost consumer mediation.

\subsection{The Role of Simplified Procedures}

As discussed in Section 2.2, the most common simplified procedures are the unilateral summary procedure (order for payment) for the collection of uncontested debts and simplified contradictory procedures for small claims, including related mediation schemes. These procedures have the aim to provide litigants with a speedy, cheap, and simple procedure, and for the government they contribute to optimising the allocation of scarce resources. The uncontested nature or the low value of the claim justifies a simplified procedure. In this regard, simplified procedures tie in perfectly with austerity measures.

In a number of countries, these procedures have been reformed with a view to austerity and/or with the general aim of increasing efficiency of civil justice. For instance, in Spain and Belgium, the order for payment procedure was reformed in recent years. For small claims procedures, the threshold has been raised substantially in particular in England, Spain, Israel, and several Canadian provinces. In July 2017, the threshold for the European small claims procedure will be raised from $€ 2,000$ to $€ 5,000 .{ }^{66}$ In addition, (compulsory) mediation and ADR schemes have been established for small value claims in particular in recent years.

Generally, the existing simplified procedures are considered to be effective, as they reduce the costs of the

63. See Owusu-Dapaa and Bediako in the present issue Silver and Farrow in the present issue.

64. See Owusu-Dapaa and Bediako in the present issue Gomez and Gomez in the present issue.

65. Giuseppe De Palo, Leonardo D'Urso, Mary Trevor et al., 'Rebooting' the mediation directive: assessing the limited impact of its implementation and proposing measures to increase the number of mediations in the European Union, report European Parliament, 2014.

66. Regulation (EU) 2015/2421 of 16 December 2015 amending Regulation (EC) No 861/2007 establishing a European Small Claims Procedure and Regulation (EC) No 1896/2006 creating a European order for payment procedure, OJ 2015, L 341 procedure, expedite proceedings, and are less burdensome, in particular for the claimant. In how far they actually contribute to effective access to justice for litigants depends upon the scope of availability, the procedural design, and their functioning in practice. Though little empirical data are available to back this up, it may be assumed that also for the government having effective simplified procedures in place, where appropriate coupled with mediation procedures, reduces the judicial backlog and will be less costly.

In a number of jurisdictions, concerns have been expressed as to the lack of sufficient protection in simplified procedures. As was mentioned above, there is a certain trade-off between procedural efficiency and procedural justice. ${ }^{67}$ The objective of increasing efficiency has been on the justice agenda of many countries for a number of years or even decades. Slow justice is endemic, as is also evidenced by the fact that over one-fourth of the violation judgements of the European Court of Justice concern the right to a trial within a reasonable time. ${ }^{68}$ Though the importance for expedited justice is clear, procedural justice should not be sacrificed on the pyre of increasing efficiency.

The Israeli article expresses concerns on the negative impact of massive attempts of reducing delays on the rights of the parties and the quality of judicial work. ${ }^{69}$ In the Brazilian article, reference is made to scholarly concerns on the excessive simplification and massification of civil procedures which may reduce substantive justice and the protection of procedural rights.

A particular point of attention is the increase of unrepresented litigants in this regard, as discussed above. ${ }^{70}$ In the United States, an industry has developed where creditors sell their claims to 'predatory collectors exploit the small claims process for profit'. ${ }^{71}$ This proliferation of pro se litigation requires an active judge, empowerment of litigants by providing accessible information, access to free legal advice, accessible (online) procedures and alternative means of adjudication, active consumer agencies, as well as sufficient review mechanisms.

\section{Concluding Remarks}

The consequences of austerity and in particular the global financial crisis are also visible in the civil justice area. The severity, however, differs per country and also depends upon the government funding of civil litigation. For instance, in the United States, where governmental litigation funding is uncommon, the effects are generally limited. In many other countries, the need to cut back costs of the judiciary has had an effect among others on court fees and the provision of legal aid. The

\footnotetext{
67. Section 2.2.1

68. Council of Europe, The European Court of Human Rights, '50 Years of Activity: Some Facts and Figures', 2009, at 6.

69. See Brosh in the present issue

70. Section 3.1.2

71. See Gomez and Gomez in the present issue.
} 
design of specific procedures for small and simple matters fit in with a cost reduction policy and with the desire to reduce lengthy and complex procedures. There is a general trend to enhance ADR mechanisms, in particular in small (consumer) cases, to get these out of the court system.

While it is inevitable that that in times of cutbacks on public expenditure the judicial budget is also affected, countries have to make the necessary investments to ensure the well-functioning of the judicial system. Not only for the sake of justice, but also because a well-functioning justice system is considered key to investments and economic development. ${ }^{72}$ In global rankings, including the World Bank Doing Business Reports ${ }^{73}$ and the Global Competitiveness Reports of the World Economic Forum, ${ }^{74}$ civil justice is an important indicator. As is highlighted in the Israeli article, a Euro Summit Statement of July 2015 on the requirements to continue financial support to Greece, stresses the need to adopt a new civil code that overhauls procedures for the civil justice system, accelerates the procedure and reduces costs significantly. ${ }^{75}$ This supports the need of a well-functioning civil justice system as a prerequisite of economic welfare.

The simplification and speeding up of civil procedure is generally considered important but seems to be valued differently. Exemplary in this regard are the articles on Canada and Israel in this issue. As Silver and Farrow discuss, in 2014, the Canadian Supreme Court expressed the need for a culture shift in civil litigation towards 'proportional procedures tailored to the needs of the particular case'. This Court stated that while the Canadian system is premised on the values of fairness and justness, the 'proportionality principle means that the best forum for resolving a dispute is not always that with the most painstaking procedure'. ${ }^{76}$ The Israeli article considers the continuing quest to speed up justice and the simplification beyond low value and simple claims as 'cutting corners'. There are strong concerns about the rights of the parties and judicial quality. Reference is made to a statement by a late Israeli Supreme Court Justice quoted by Brosh, saying that "delayed justice is preferable to swift injustice", 77 countering the saying that "justice delayed is justice denied". This is in line with concerns on the pursuit for simplification and acceleration expressed in the Brazilian article. ${ }^{78}$

72. See also EU Commissioner Jourová in the preface to the EU Justice Scoreboard of 2015; OECD Economic Policy Paper, Judicial performance and its determinants: a cross-country perspective, a going for growth report, June 2013, p. 6

73. World Bank Group, Doing Business 2016 - Measuring Regulatory Quality and Efficiency, available at: <www.doingbusiness.org $>$.

74. World Economic Forum, The Global Competitiveness Report 2015-2016, available at: <www.weforum.org/>.

75. Brosh in the present issue. See Council of the European Union, Euro Summit Statement (SN 4070/15), Brussels, 12 July 2015, available at: $<$ www.consilium.europa.eu/en/meetings/european-council/2015/07/ $12 />$.

76. See Silver and Farrow in the present issue, referring to Hryniak v. Mauldin, 2014 SCC 7, paras. 2, 27, 28 [2014] 1 SCR 87.

77. See Brosh in the present issue.

78. Section 3.2.
Apprehension for procedural rights and judicial quality resulting from oversimplification, budgetary constraints and the financial inability of a party to employ legal representation, have to be taken seriously. At the same time it should be acknowledged that, while the need for cost reduction may not be the most appropriate incentive for procedural reform, countries that cannot adjust sufficiently to austerity and to the need to modernise the judiciary and procedure might in the long term face an unsustainable civil justice system. 